\title{
ANALISIS PERBANDINGAN MODEL ALTMAN MODIFIKASI DAN SPRINGATE UNTUK MEMPREDIKSI KEBANGKRUTAN PADA PERUSAHAAN PERBANKAN YANG TERDAFTAR DI BURSA EFEK INDONESIA SEBELUM DAN SESUDAH ADANYA LEMBAGA PENJAMIN SIMPANAN
}

\author{
Unggul Nusantoro Ari Bowo* \\ Sri Ayem \\ Prodi Akuntansi Fakultas Ekonomi \\ Universitas Sarjanawiyata Tamansiswa \\ *E-mail: bowounggul@gmail.com
}

\begin{abstract}
This study aims to compare the Modified Altman and Springate models in predicting bankruptcy of the banking company before and after the LPS. Populations that are objects of this research are banking companies listed in Indonesia Stock Exchange. The samples used were 21 banking companies listed in Indonesia Stock Exchange. The sample was banking company that is always present financial statements in a row before and after the LPS. This study uses a model of the formula and the Modification Altman Springate models after it uses different test analysis of paired sample t test to determine differences in outcome prediction of corporate bankruptcy banks.

From the results of hypothesis testing before the founding of the LPS models Modification Altman and Springate models do not have a difference in predicting bankruptcy of the banking company. Meanwhile, after the founding of the LPS models Modification Altman and Springate models there is a difference in predicting bankruptcy of the banking company.
\end{abstract}

Keywords: Modified Altman, Springate, Bankruptcy, LPS

\section{PENDAHULUAN \\ Latar Belakang}

Dalam lingkungan yang semakin turbulen, sistem dan sub-sistem organisasi menjadi makin terbuka dan tingkat persaingan semakin ketat dan tajam, bahkan semakin tidak menentu arah perubahannya (Endri, 2009). Untuk mempertahankan kelangsungan hidup dalam sistem keuangan yang turbulen, suatu bank harus dapat berkompetisi dengan bank lainnya sebagai kompetitor dan sebagai mitra unit lainnya yang juga memberikan produk/layanan yang sama. Suatu bank berhasil memenangkan kompetisi bisnisnya jika ia mampu memberikan produk/jasa layanan lebih baik daripada kompetitornya, sekaligus mampu beradaptasi dengan setiap perubahan lingkungan. Dengan kemampuan manajerial yang dimiliki, para manajer perusahaan diharapkan mampu mengubah ancaman lingkungan yang turbulen menjadi berbagai peluang usaha yang menguntungkan. Manajemen bank yang kreatif-inovatif selalu berusaha menciptakan berbagai produk/layanan yang prospektif dan menguntungkan tanpa mengabaikan prinsip asset liability management (ALMA), yaitu menyelaraskan antara profitabilitas dan risiko (Hadad et. al., 2003:1).

Pada tahun 2004 pemerintah mengeluarkan Undang-undang No. 24 tahun 2004 tentang Lembaga Penjamin Simpanan yang sering disingkat dengan LPS untuk menguatkan kondisi moneter perbankan. Salah satu isi dari undang-undang tersebut yaitu ketentuan tentang penjaminan simpanan nasabah seperti pada Pasal 10 yang menjelaskan simpanan nasabah yang berbentuk giro, deposito, sertifikat deposito, 
tabungan dan/atau bentuk lainnnya yang dipersamakan dengan itu dijamin oleh LPS. Dalam hal ini LPS mempunyai peran menjamin dana nasabah yag disimpan di bank yang terdaftar di lembaga tersebut. Masyarakat tentu akan lebih merasa aman dan nyaman dengan adanya lembaga ini. Nilai simpanan yang dijamin oleh LPS paling tinggi sebesar Rp 2 milyar per nasabah per bank sejak tanggal 13 Oktober 2008. Nilai simpanan yang dijamin tersebut meliputi pokok ditambah bunga untuk bank konvensional, atau pokok ditambah bagi hasil yang telah menjadi hak nasabah untuk bank syariah.

Munculnya berbagai model prediksi kebangkrutan merupakan antisipasi dan sistem peringatan dini terhadap financial distress karena model tersebut dapat digunakan sebagai sarana untuk mengidentifikasikan bahkan memperbaiki kondisi sebelum sampai pada kondisi krisis atau kebangkrutan. Kondisi perusahaan yang terdeteksi lebih awal, sangat memungkinkan bagi perusahaan, investor dan para kreditor (lembaga keuangan) serta pemerintah melakukan langkah-langkah antisipatif untuk mencegah agar krisis keuangan segera tertangani (Endri, 2009).

Menurut Altman (2000) dalam Endri (2009) teknik penggunaan MDA (multivariate discriminant analysis) mempunyai kelebihan dalam mempertimbangkan karakteristik umum dari perusahaan-perusahaan yang relevan, termasuk interaksi antar perusahaan tersebut. Pendekatan MDA dapat mengkombinasikan berbagai rasio menjadi suatu model prediksi yang berarti dan dapat digunakan untuk seluruh perusahaan, baik perusahaan publik, pribadi, manufaktur, ataupun perusahaan jasa dalam berbagai ukuran. Kelemahan dari model ini adalah tidak ada rentang waktu yang pasti kapan kebangkrutan akan terjadi setelah hasil Z-score diketahui lebih rendah dari standar yang ditetapkan. Model ini juga tidak dapat mutlak digunakan karena adakalanya terdapat hasil yang berbeda jika kita menggunakan obyek yang berbeda.
Seperti halnya Altman, Model Springate adalah model rasio yang menggunakan multivariate discriminant analysis (MDA). Dalam metode MDA diperlukan lebih dari satu rasio keuangan yang berkaitan dengan kebangkrutan perusahaan untuk membentuk suatu model yang baik. Untuk menentukan rasio-rasio yang dapat mendeteksi kemungkinan kebangkrutan, Springate menggunakan MDA untuk memililh 4 rasio dari 19 rasio keuangan yang populer dalam literaturliteratur, yang mampu membedakan secara terbaik antara sound business yang pailit dan tidak pailit.

Banyak model analisis yang dapat digunakan untuk memprediksi kebangkrutan. Beberapa contohnya adalah Model Altman (1968,1984), Springate (1978), Ohslon (1980), Whalen dan Thomson (1988). Namun dari beberapa model analisis tersebut, analisis kebangkrutan yang sering digunakan adalah Analisis Z-Score model Altman dan model Springate. Analisis kebangkrutan tersebut dikenal karena selain caranya mudah, keakuratan dalam menentukan prediksi kebangkrutannya pun cukup akurat. Formula Z-Score digunakan untuk memprediksi kebangkrutan dari Altman dan Springate merupakan sebuah multivariate formula yang digunakan untuk mengukur kesehatan finansial dari perusahaan. Altman menemukan lima jenis rasio keuangan dan Springate empat jenis rasio yang dapat dikombinasikan untuk melihat perbedaaan antara perusahaan yang bangkrut dan yang tidak bangkrut.

Penelitian yang dilakukan Ayu dan Niki (2009) pada perusahaan manufaktur yang diprediksi bangkrut dengan menggunakan ketiga model Altman, untuk kelompok perusahaan berumur kurang dari 30 tahun memiliki persentase prediksi kebangkrutan yang paling tinggi dari pada kelompok perusahaan manufaktur lebih dari 30 tahun. Gunardiansya (2004) Implemantasi nilai $Z$-score dengan keadaan perusahaan sesungguhnya sangat penting. Karena prediksi dari Z-score harus dibandingkan dengan keadaan yang sesungguhnya dari 
masing-masing perusahaan baja di BEI. Sehingga prediksi dengan menggunakan metode Z- score dapat dipercaya hasilnya.

Sementara Hafiz dan Dicky (2012) yang meneliti industri properti menyatakan terdapat 6 perusahaan yang bangkrut dan tidak bangkrut, ditemukan model Altman tahun 2006 pada posisi grey area dan model Springate ditemukan tahun 2005 ada satu perusahaan, satu perusahaan tahun 2007, dua perusahaan tahun 2008, dan satu perusahaan tahun 2009 berada posisi tidak bangkrut. Luciana dan Emanuel (2003) menambahkan beberapa variabel rasio keuangan yang paling dominan dalam menentukan financial distress suatu perusahaan adalah: (1) rasio profit margin yaitu laba bersih dibagi dengan penjualan (NI/S), (2) rasio financial leverage yaitu hutang lancar dibagi dengan total aktiva (CL/TA), (3) rasio likuiditas yaitu aktiva lancar dibagi dengan hutang lancar (CA/CL), (4) rasio pertumbuhan yaitu rasio pertumbuhan laba bersih dibagi dengan total aktiva (GROWTH NI/TA).

Penelitian ini melanjutkan penelitianpenelitian sebelumnya dengan beberapa perbedaan yang cukup mendasar. Seperti yang pernah diteliti oleh Ayu dan Niki (2009), mereka menggunakan 3 metode sekaligus yaitu Altman Z-score pertama, revisi, dan modifikasi dengan sampel perusahaan manufaktur. Sementara Endri (2009) menggunakan metode Altman Zscore pertama dengan menggunakan sampel perusahaan perbankan syariah. Dengan melihat, mengacu dan melanjutkan pada penelitian sebelumnya dan masih jarangnya penelitian yang memprediksi kebangkrutan perusahaan-perusahaan perbankan sebelum dan sesudah munculnya LPS maka penulis tertarik untuk mengetahui perbandingan antara model Altman Modifikasi (1995) dan model Springate (1978) dalam memprediksi kebangkrutan bank yang terdaftar di Bursa Efek Indonesia.

\section{Rumusan Masalah}

a. Bagaimanakah model Altman Modifikasi dan model Springate dalam memprediksi kebangkrutan perusahaan perbankan yang ada di Bursa Efek Indonesia pada periode sebelum dan sesudah terbentuknya Lembaga Penjamin Simpanan?

b. Apakah terdapat perbedaan antara model Altman Modifikasi dan model Springate dalam memprediksi kebangkrutan perusahaan perbankan yang terdaftar di Bursa Efek Indonesia?

\section{METOdOLOGI PENELITIAN}

Penelitian ini mengambil sampel dengan metode purposive sampling, yaitu metode pengambilan sampel dari populasi berdasarkan kriteria tertentu dengan tujuan untuk mendapatkan sampel presentatif (Sugiyono, 2008). Dan kriteria pengambilan sampelnya adalah :

1. Perusahaan Perbankan yang terdaftar di Bursa Efek Indonesia.

2. Perusahaan Perbankan yang selalu menyajikan laporan keuangan berturutturut selama periode pengamatan 2002 2007.

3. Perusahaan Perbankan yang selalu menyajikan laporan keuangan berturutturut sebelum dan setelah berdirinya Lembaga Penjamin Simpanan.

4. Data yang diperlukan untuk penelitian tersedia dengan lengkap.

Tabel 1

Penentuan Sampel Penelitian

\begin{tabular}{|c|c|}
\hline KRITERIA SAMPEL & JU \\
\hline $\begin{array}{c}\text { Perusahaan perbankan yang terdaftar di BEI } \\
\text { pada tahun 2002-2007 }\end{array}$ & 29 \\
\hline $\begin{array}{c}\text { Perusahaan perbankan pada tahun 2002-2007 } \\
\text { yang tidak memenuhi criteria }\end{array}$ & 8 \\
\hline
\end{tabular}




\begin{tabular}{|l|l|}
\hline Total Sampel & 21 \\
\hline Jumlah observasi selama 6 tahun & 126 \\
\hline
\end{tabular}

Sumber: Indonesian Capital Market Directory (ICMD 2002-2007)

Tabel 2

Perusahaan Perbankan yang Terdaftar di BEI Periode 2002-2007

\begin{tabular}{|c|c|c|c|c|c|}
\hline No & \begin{tabular}{|l|} 
Kode \\
Bank \\
\end{tabular} & $\begin{array}{l}\text { Nama } \\
\text { Perusahaan/Bank }\end{array}$ & No & \begin{tabular}{|l|} 
Kode \\
Bank \\
\end{tabular} & $\begin{array}{l}\text { Nama } \\
\text { Perusahaan/Bank }\end{array}$ \\
\hline 1. & BABP & $\begin{array}{l}\text { PT. Bank } \\
\text { Bumiputera } \\
\text { Indonesia Tbk }\end{array}$ & 11. & BNGA & PT. Bank Niaga Tbk \\
\hline 2. & BBCA & $\begin{array}{l}\text { PT. Bank Central } \\
\text { Asia Tbk }\end{array}$ & 12. & BNII & $\begin{array}{ll}\text { PT. } & \text { Bank } \\
\text { Internasional } & \\
\text { Indonesia Tbk } & \end{array}$ \\
\hline 3. & BBIA & $\begin{array}{l}\text { PT. Bank Buana } \\
\text { Indonesia Tbk }\end{array}$ & 13. & BNLI & $\begin{array}{lll}\text { PT. Bank } & \text { Permata } \\
\text { Tbk } & & \\
\end{array}$ \\
\hline 4. & BBNI & $\begin{array}{l}\text { PT. Bank Negara } \\
\text { Indonesia Tbk }\end{array}$ & 14. & BSWD & $\begin{array}{l}\text { PT. Bank Swadesi } \\
\text { Tbk }\end{array}$ \\
\hline 5 . & BBNP & $\begin{array}{l}\text { PT. Bank } \\
\text { Nusantara } \\
\text { Parahyangan } \\
\text { Tbk }\end{array}$ & 15. & BVIC & $\begin{array}{l}\text { PT. Bank Victoria } \\
\text { International Tbk }\end{array}$ \\
\hline 6. & BCIC & $\begin{array}{l}\text { PT. Bank Century } \\
\text { Tbk }\end{array}$ & 16. & INPC & $\begin{array}{l}\text { PT. Bank Inter- } \\
\text { Pacific Tbk }\end{array}$ \\
\hline 7. & BDMN & $\begin{array}{l}\text { PT. Bank Danamon } \\
\text { Indonesia Tbk }\end{array}$ & 17. & LPBN & PT. Bank Lippo Tbk \\
\hline 8. & BEKS & $\begin{array}{l}\text { PT. Bank Eksekutif } \\
\text { Internasional } \\
\text { Tbk }\end{array}$ & 18. & MAYA & $\begin{array}{l}\text { PT. Bank Mayapada } \\
\text { Internasional Tbk }\end{array}$ \\
\hline 9. & BKSW & $\begin{array}{l}\text { PT. Bank Kesawan } \\
\text { Tbk }\end{array}$ & 19. & MEGA & PT. Bank Mega Tbk \\
\hline \multirow[t]{2}{*}{10.} & \multirow[t]{2}{*}{ BMRI } & \multirow[t]{2}{*}{$\begin{array}{l}\text { PT. Bank Mandiri } \\
\text { Tbk }\end{array}$} & 20 & NISP & PT. Bank NISP Tbk \\
\hline & & & 21. & PNBN & PT. Bank Panin Tbk \\
\hline
\end{tabular}

Sumber: Indonesian Capital Market Directory (2002-2007)

\section{Sumber Data}

Data yang diperlukan dalam penelitian ini adalah data sekunder yang berupa laporan keuangan tahunan perusahaan perbankan dari tahun 2002 2007. Sumber datanya diperoleh dari ICMD (Indonesian Capital Market Directory) perbankan periode tahun 2002 sampai dengan 2007.

\section{Metode Pengumpulan Data}

Ada dua metode yang digunakan peneliti dalam mengumpulkan data, yaitu :
1. Penelitian Lapangan

Kegiatan yang dilakukan dalam penelitian lapangan ini adalah mengumpulkan data dari pojok bursa FE UST.

2. Penelitian Kepustakaan

Kegiatan yang dilakukan dalam penelitian kepustakaan ini adalah melakukan kajian pada sumber bacaan dan berbagai penelitian terdahulu untuk mengetahui kaitan antara penelitian yang penulis lakukan dengan penelitian 
sebelumnya. Data tersebut diperlukan untuk analisis terhadap permasalahan dan pencatatan teori-teori yang telah dipelajari pada peristiwa yang terjadi.

\section{Metode Analisis Data}

Setelah dihitung dengan kedua metode baik Altman Modifikasi maupun Springate dengan formula sebagai berikut:

1. Formula Altman Z-Score Modifikasi

Penelitian ini akan menggunakan analisa potensi kebangkrutan perusahaan perbankan dengan menggunakan metode Altman sebagai salah satu alat analisis datanya. Metode yang ditemukan Altman tersebut dikenal dengan Z-Score. Dari data laporan keuangan perusahaan akan dianalisis dengan menggunakan beberapa rasio keuangan yang dianggap dapat memprediksi kebangkrutan sebuah perusahaan. Data atau hasil perhitungan akan dianalisis lebih jauh lagi dengan menggunakan sebuah formula yang ditemukan Altman yaitu:

$$
\mathrm{Z}-\text { Score }=6,56 \mathrm{XI}+3,26 \mathrm{X} 2+6,72 \mathrm{X3}+1,05 \mathrm{X} 4
$$

Keterangan:

$$
\begin{aligned}
& \mathrm{X} 1=\text { working capital } / \text { total asset } \\
& \quad \mathrm{X} 2=\text { retained earnings } / \text { total asset } \\
& \mathrm{X} 3=\text { earning before interest and taxes/total asset } \\
& \mathrm{X} 4=\text { market value of equity } / \text { book value of total debt }
\end{aligned}
$$

Nilai $\mathrm{Z}$ adalah indeks keseluruhan fungsi multiple discriminant analysis. Menurut Altman, terdapat angka-angka cut off nilai $\mathrm{z}$ yang dapat menjelaskan apakah perusahaan akan mengalami kegagalan atau tidak pada masa mendatang dan ia membaginya ke dalam tiga kategori, yaitu:

a. Jika nilai $\mathrm{Z}<1,1$ maka termasuk perusahaan yang bangkrut.

b. Jika nilai $1,1<\mathrm{Z}<2,6$ maka termasuk grey area (tidak dapat ditentukan apakah perusahaan sehat ataupun mengalami (kebangkrutan). c. Jika nilai $\mathrm{Z}>2,6$ maka termasuk perusahaan yang tidak bangkrut.

2. Formula Springate

Model ini dikembangkan oleh Springate (1978) dengan menggunakan analisis multidiskriminan, dengan menggunakan 40 perusahaan sebagai sampelnya. Model ini dapat digunakan untuk memprediksi kebangkrutan dengan tingkat keakuratan 92,5\%. Model yang dikembangkan oleh Springate adalah:

$$
Z=1,03 A+3,07 B+0,66 C+0,4 D
$$

Keterangan :

$\mathrm{A}=$ working capital/total asset

$\mathrm{B}=$ net profit before interest and taxes/total asset

$\mathrm{C}=$ net profit before taxes/current liabilities

$\mathrm{D}=$ sales / total asset

Model tersebut mempunyai standar dimana perusahaan yang mempunyai skor $\mathrm{Z}>0,862$ diklasifikasikan sebagai perusahaan sehat, sedangkan perusahaan yang mempunyai skor $\mathrm{Z}<0,862$ diklasifikasikan sebagai perusahaan potensial bangkrut. 
Selanjutnya dipisahkan dari tahun sebelum dan sesudah berdirinya Lembaga Penjamin Simpanan, sehingga terdapat 4 kelompok yaitu :

1. Kelompok pertama yang terdiri dari tahun 2002, 2003, dan 2004 untuk metode Altman modifikasi.

2. Kelompok kedua yang terdiri dari tahun 2005, 2006, dan 2007 untuk metode Altman modifikasi.

3. Kelompok ketiga yang terdiri dari tahun 2002, 2003, dan 2004 untuk metode Springate.

4. Kelompok terakhir yang terdiri dari tahun 2005, 2006, dan 2007 untuk metode Springate.

Untuk mengetahui perbedaan model Altman Modifikasi dan model Springate dalam mengukur prediksi kebangkrutan pada perusahaan perbankan yang terdaftar di BEI, maka metode yang digunakan dalam menganalisis data dalam penelitian ini adalah uji beda $t$ paired samples test. Uji ini digunakan untuk mengetahui ada atau tidaknya perbedaan rata-rata antara dua kelompok sampel yang berpasangan (berhubungan). Maksudnya disini adalah sebuah sampel tetapi mengalami dua perlakuan yang berbeda. Data yang digunakan biasanya berskala interval atau rasio. Langkah-langkah pengujian sebagai berikut:

Hipotesis penelitian

Ho : Tidak terdapat perbedaan yang signifikan antara analisis kebangkrutan Model Altman Modifikasi dan Model

\section{HASIL PENELITIAN DAN PEMBAHASAN}

Tahap-tahap perhitungan dengan kedua metode baik Altman Modifikasi dan Springate sebelum dan sesudah berdirinya Lembaga Penjamin Simpanan

\section{Metode Altman}

\section{X1 (Working Capital / Total Asset)}

Contoh perhitungan $\mathrm{X} 1$ tahun 2002 untuk BABP :

$$
\begin{gathered}
\text { X1 }=(\text { Working Capital } / \text { Total Asset }) \\
\text { X1 } 2002=294936 / 2330030 \\
=0,127
\end{gathered}
$$

Springate pada perusahaan perbankan yang terdaftar di Bursa Efek Indonesia pada periode sebelum dan sesudah terbentuknya Lembaga Penjamin Simpanan.

Ha : Terdapat perbedaan yang signifikan antara analisis kebangkrutan model Altman Modifikasi dan model Springate pada perusahaan perbankan yang terdaftar di Bursa Efek Indonesia pada periode sebelum dan sesudah terbentuknya Lembaga Penjamin Simpanan.

Pengujian menggunakan uji dua sisi dengan tingkat signifikansi $=5 \%$. Tingkat signifikansi dalam hal ini berarti kita mengambil risiko salah dalam mengambil keputusan untuk menolak hipotesis yang benar sebanyak-banyaknya $5 \%$. Kesimpulan jika nilai $\mathrm{P}$ value lebih besar dari tingkat signifikansi $(0,05)$ maka Ho didukung. Hal ini berarti tidak terdapat perbedaan yang signifikan antara analisis kebangkrutan Model Altman Modifikasi dan Model Springate pada perusahaan perbankan yang terdaftar di Bursa Efek Indonesia pada periode sebelum dan sesudah terbentuknya Lembaga Penjamin Simpanan. Jika nilai P value lebih kecil dari tingkat signifikansi $(0,05)$ maka Ho tidak didukung. Hal ini berarti Terdapat perbedaan yang signifikan antara analisis kebangkrutan model Altman Modifikasi dan model Springate pada perusahaan perbankan yang terdaftar di Bursa Efek Indonesia pada periode sebelum dan sesudah terbentuknya Lembaga Penjamin Simpanan.

Dari hasil perhitungan modal kerja terhadap total asset yang dimiliki 21 perusahaan perbankan yang terdaftar di Bursa Efek Indonesia dalam kurun waktu 6 tahun (2002-2007), terdapat 19 perusahaan perbankan yang mempunyai nilai positif, hal ini berarti nilai modal kerja bersihnya mampu untuk melunasi kewajiban jangka pendeknya. Hanya ada 2 bank yang mempunyai nilai negatif setiap tahunnya yaitu BEKS dan LPBN, ini berarti keduanya kemungkinan besar akan menghadapi kesulitan dalam 
menutupi kewajiban jangka pendeknya dan hal tersebut merupakan salah satu indikator untuk mengukur kebangkrutan.

2. X2 (Retained Earnings / Total Asset) Contoh perhitungan X2 tahun 2002 untuk BABP :

$\mathrm{X2}=$ Retained Earnings / Total Asset

$$
\begin{aligned}
\mathrm{X} 22002 & =\mathbf{2 6 8 6 8} / 2330030 \\
= & \mathbf{0 , 0 1 2}
\end{aligned}
$$

Dari hasil perhitungan laba ditahan terhadap total asset yang dimiliki 21 perusahaan perbankan terdapat 14 bank yang mempunyai nilai $\mathrm{X} 2$ positif selama 6 tahun. Terdapat 5 bank yang selama periode pengamatan selalu mempunyai nilai negatif ini dikarenakan nilai retained earnings yang selalu negatif yaitu BCIC, BKSW, BNLI, INPC dan LPBN. Terdapat satu bank yang mengalami penurunan setelah munculnya LPS yaitu BEKS. Hal ini dapat diartikan yang mempunyai nilai X2 negatif tersebut sangat berpotensi bangkrut.

3. X3 (Earning Before Interest and Tax / Total Asset)

Contoh perhitungan X3 tahun 2002 untuk BABP :

$\mathrm{X3}=$ (Earning Before Interest and

Tax / Total Asset)

$\mathrm{X32002}=\mathbf{2 7 2 3 8 3} / \mathbf{2 3 3 0 0 3 0}$

$$
=0,117
$$

Dari hasil perhitungan nilai $\mathrm{X} 3$ dapat terlihat BABP di tahun 2002 menunjukkan untuk setiap Rp. 1 aktiva hanya mampu menjamin nilai EBIT sebesar 0,117 , belum dapat menghasilkan laba sebelum bunga dan pajak lebih besar dari Rp. 1. Hasil yang hampir sama juga terlihat dalam perhitungan laba sebelum bunga dan pajak terhadap total aktiva yang dimiliki 21 perusahaan perbankan maka dapat terlihat bahwa asset produktif perusahaan perbankan belum mampu menghasilkan laba usaha seperti yang telah direncanakan.
4. X4 (Book Value of Equity to Book Value of Total Liabilities)

Contoh perhitungan X4 tahun 2002 untuk BABP :

X4 = (Book Value of Equity / Book

Value of Total Liabilities)

$\mathrm{X} 42002=232017 / 2098013$

$$
=0,111
$$

Dari perhitungan nilai buku ekuitas terhadap nilai buku total kewajiban, dapat diketahui BABP di tahun 2002 menunjukkan setiap $\mathrm{Rp} 1$ nilai hutang hanya mampu membiayai nilai aktiva sebesar 0,111 . Sedangkan 21 perusahaan perbankan mempunyai nilai yang fluktuatif cenderung naik turun dari tahun ke tahun, padahal nilai X4 yang baik adalah ketika nilai X4 ini mengalami penurunan yang berarti nilai hutang perusahaan perbankan juga mengalami penurunan. Ada 2 bank yang mengalami penurunan nilai $\mathrm{X} 4$ yaitu BBNI dan BSWD walaupun nilai penurunannya relatif kecil.

5. Perhitungan Z-score Altman Modifikasi Contoh perhitungan nilai Z-score tahun 2002 untuk BABP :

$\mathrm{Z} \quad$ Score $=6,56 \mathrm{XI}+3,26 \mathrm{X} 2+6,72 \mathrm{X} 3+$ 1,05X4

$$
\begin{aligned}
& =\quad 6,56(0,127)+3,26(0,012)+ \\
& 6,72(0,117)+1,05(0,111) \\
& =1,770(\text { grey area })
\end{aligned}
$$

Dan hasil Perhitungan model Altman Modifikasi seluruhnya adalah sebagai berikut :

1. Tahun 2002 : 10 diprediksi bangkrut, 2 diprediksi tidak bangkrut, 10 diprediksi grey area

2. Tahun 2003 : 12 diprediksi bangkrut, 9 diprediksi grey area

3. Tahun $2004: 11$ diprediksi bangkrut, 10 diprediksi grey area

4. Tahun 2005: 13 diprediksi bangkrut, 8 diprediksi grey area

5. Tahun $2006: 7$ diprediksi bangkrut, 14 diprediksi grey area

6. Tahun $2007: 11$ diprediksi bangkrut, 10 diprediksi grey area 


\section{Metode Springate}

1. A (Working Capital / Total Asset)

Rasio A pada metode Springate ini sama dengan rasio $\mathrm{X} 1$ pada perhitungan metode Altman modifikasi.

\section{B (Earning Before Interest and Taxes / Total Assets)}

Rasio B pada metode Springate ini sama dengan rasio $\mathrm{X} 3$ pada perhitungan metode Altman modifikasi.

\section{C (Net Profit Before Taxes / Current} Liabilities)

Rasio ini membandingkan antara laba sebelum pajak terhadap kewajiban lancar. Contoh perhitungan nilai $\mathrm{C}$ untuk BABP di tahun 2002:

\section{$\mathrm{C}=$ (Net profit Before Taxes/} Current Liabilities)

C2002 = 27487/1908767

$$
=0,561
$$

Dari hasil perhitungan laba sebelum pajak terhadap kewajiban lancar yang dimiliki 21 perusahaan perbankan yang terdaftar di Bursa Efek Indonesia dalam kurun waktu 6 tahun rata-rata memiliki nilai yang fluktuatif cenderung naik turun dari tahun ke tahun padahal nilai yang baik adalah ketika laba sebelum pajak yang dihasilkan lebih besar daripada nilai kewajiban lancarnya sehingga nilai perbandingan keduanya relatif lebih kecil.

\section{D (sales / total asset)}

Rasio ini membandingkan jumlah pendapatan/penjualan terhadap total aset. Disebut juga dengan assets turnover dan biasanya dipergunakan untuk mengukur tingkat efisiensi suatu bisnis dalam memanfaatkan aset yang dimiliki. Karena nilai assets turnover berbedabeda untuk tiap-tiap industri, kita harus lebih bijak dalam menafsirkan angka ini. Contoh perhitungan nilai $\mathrm{D}$ di tahun 2002 untuk BABP:

$$
\begin{array}{ll}
\mathrm{D} & =\text { Sales } / \text { Total Asset } \\
\mathrm{D} 2002 & =\mathbf{3 6 3 9 2 4} / 2330030 \\
& =\mathbf{0 , 1 5 6}
\end{array}
$$

Dari hasil perhitungan penjualan terhadap total aset pada 21 perusahaan perbankan selama 6 tahun, maka dapat terlihat kemampuan manajemen perbankan dalam menghadapi persaingan tergolong belum cukup baik karena belum mampu menghasilkan penjualan lebih besar dari Rp.1 untuk setiap Rp.1 total aset.

5. Perhitungan $\mathrm{Z}$-score Springate

$$
\begin{aligned}
& \text { Z-Score }=1,03 \mathrm{~A}+3,07 \mathrm{~B}+\mathbf{0 , 6 6 C} \\
& +\mathbf{0 , 4 D} \\
& =1,03(0,127)+3,07(0,012)+ \\
& \quad 0,66(0,014)+0,4(0,156) \\
& =0,561(\text { Potensial bangkrut })
\end{aligned}
$$

Dan hasil keseluruhan perhitungan model Springate adalah sebagai berikut :

1. Tahun 2002 : 21 diprediksi potensi bangkrut

2. Tahun 2003 : 21 diprediksi potensi bangkrut

3. Tahun 2004 : 21 diprediksi potensi bangkrut

4. Tahun 2005: 21 diprediksi potensi

\begin{tabular}{|c|c|c|c|}
\hline & & $\begin{array}{r}\text { Sig. } \\
(2 \text {-tailed) }\end{array}$ & Kesimpulan \\
\hline $\begin{array}{l}\text { Altman Sebelum LPS } \\
\text { dan Springate Sebelum } \\
\text { LPS }\end{array}$ &, 513 & 0,135 & $\begin{array}{l}\text { Nilai signifikasi lebih besar dari } \\
\text { tingkat signifikan sebesar } 0,05(0,135 \\
>0,05) \text { sehingga Ho didukung }\end{array}$ \\
\hline
\end{tabular}
bangkrut

5. Tahun 2006 : 21 diprediksi potensi bangkrut

6. Tahun 2007 : 21 diprediksi potensi bangkrut

\section{Pembahasan Hasil Pengujian Hipotesis}

Tabel 3

Metode Altman 
Berdasarkan hasil pengolahan data melalui SPSS maka nilai paired samples test dapat terlihat jika nilai t hitung sebesar 1,513 dengan nilai signifikasi sebesar 0,135 lebih besar dari tingkat signifikan sebesar 0,05 sehingga Ho didukung. Hal ini berarti sebelum berdirinya Lembaga Penjamin Simpanan untuk kedua metode Altman
Modifikasi dan metode Springate tidak terdapat perbedaan yang signifikan. Dengan demikian dapat dinyatakan bahwa sebelum berdirinya Lembaga Penjamin Simpanan kedua metode ini, baik Altman Modifikasi dan Springate menunjukkan hasil yang sama dalam memprediksi kebangkrutan untuk 21 perusahaan perbankan.

Tabel 4

Metode Springate

\begin{tabular}{|l|l|c|l|}
\hline & & \multicolumn{1}{|c|}{ Sig. } & \multicolumn{1}{|c|}{ Kesimpulan } \\
\hline $\begin{array}{l}\text { Altman Setelah LPS } \\
\text { dan Springate Setelah } \\
\text { LPS }\end{array}$ &, 001 & 0,00 & $\begin{array}{l}\text { Nilai signifikasi lebih kecil dari } \\
\text { tingkat signifikan sebesar 0,05 }(0,00< \\
\text { 0,05) sehingga Ho didukung }\end{array}$ \\
\hline
\end{tabular}

Berdasarkan hasil pengolahan data melalui SPSS maka nilai paired samples test dapat terlihat jika nilai t hitung sebesar 7,001 dengan nilai signifikasi sebesar 0,000 lebih kecil dari tingkat signifikan sebesar 0,05 sehingga Ho tidak didukung. Hal ini berarti setelah berdirinya Lembaga Penjamin Simpanan untuk kedua metode Altman Modifikasi dan metode Springate mempunyai perbedaan yang signifikan. Dengan demikian dapat dinyatakan bahwa setelah berdirinya Lembaga Penjamin Simpanan kedua metode ini, baik Altman Modifikasi dan Springate menunjukkan hasil yang berbeda dalam memprediksi kebangkrutan untuk 21 perusahaan perbankan.

\section{Kesimpulan}

1. Model Altman Modifikasi sebelum berdirinya Lembaga Penjamin Simpanan memprediksi perusahaan perbankan yang mengalami kebangkrutan sebanyak 9 bank di tahun 2002, 12 bank di tahun 2003, dan 11 bank di tahun 2004. Untuk yang diprediksi grey area sebanyak 10 bank di tahun 2002, 9 bank di tahun 2003, dan 10 bank di tahun 2004. Selain itu terdapat 2 bank yang diprediksi dalam keadaan sehat di tahun 2002.

2. Model Altman Modifikasi setelah berdirinya Lembaga Penjamin Simpanan memprediksi perusahaan perbankan yang mengalami kebangkrutan sebanyak 13 bank di tahun 2005, 7 bank di tahun 2006, dan 11 bank di tahun 2007. Sedangkan yang diprediksi grey area sebanyak 8 bank di tahun 2005, 14 bank di tahun 2006, dan 10 bank di tahun 2007.

3. Model Springate sebelum berdirinya Lembaga Penjamin Simpanan memprediksi sebanyak 21 perusahaan perbankan dalam keadaan potensial bangkrut dan hal yang sama juga terjadi setelah berdirinya Lembaga Penjamin Simpanan yaitu 21 perusahaan perbankan dalam prediksi potensial bangkrut.

4. Berdasarkan hasil uji paired sample test sebelum berdirinya Lembaga Penjamin Simpanan model Altman Modifikasi dan model Springate tidak mempunyai perbedaan. Hal ini ditunjukkan dengan nilai signifikasi untuk kedua model Altman Modifikasi dan Springate sebesar 0,135 lebih besar dari tingkat signifikan sebesar 0,05 (0,135>0,05), sehingga Ho didukung hal ini berarti tidak terdapat perbedaan hasil prediksi yang signifikan antara model Altman Modifikasi dengan model Springate pada periode sebelum berdirinya Lembaga Penjamin Simpanan.

5. Berdasarkan hasil uji paired sample test setelah berdirinya Lembaga Penjamin Simpanan model Altman Modifikasi dan model Springate mempunyai perbedaan. 
Hal ini ditunjukkan dengan nilai signifikasi untuk kedua model Altman Modifikasi dan Springate sebesar 0,00 lebih kecil dari tingkat signifikan sebesar $0,05(0,00<0,05)$, sehingga Ho tidak didukung hal ini berarti terdapat perbedaan hasil prediksi yang signifikan antara metode Altman Modifikasi dengan metode Springate pada periode setelah berdirinya Lembaga Penjamin Simpanan.

\section{Daftar Pustaka}

Akhyar, Muhammad Adnan. (2000). Analisis Tingkat Kesehatan Perusahaan Untuk Memprediksi Potensi Kebangkrutan Dengan Pendekatan Altman. Dalam JAAI Vol.4 No. 2 Desember.

Adnan dan Arisudhana (2011). Analisis Kebangkrutan Model Altman ZScore dan Springate Pada Perusahaan Industri Property.

Ayu dan Niki (2009). Perbandingan Analisis Prediksi Kebangkrutan Menggunakan Model Altman Pertama, Almant Revisi, Dan Almant Modifikasi Dengan Ukuran Dan Umur Perusahaan Sebagai Variabel Penjelas (Studi Pada Perusahaan Manufaktur Yang Terdaftar Di Bursa Efek Indonesia). Siasat Bisnis Vol. 13 No. 1.

Bambang dan Elen (2010). Tobin's $Q$ Dan Almant Z-Score Sebagai Indikator Pengukuran Kinerja Perusahaan. Kajian Akuntansi Vol. 2 No. 1.

Endri (2009). Prediksi Kebangkrutan Bank Untuk Menghadapi Dan Mengelola Perubahan Lingkungan Bisnis: Analisis Model Almant's ZScore. Perbanas Quaterly Review Vol 2 No 1.

Guniardiansya (tt). Analisis Metode Z-Score Untuk Memprediksi Kebangkrutan Industri Baja Di BEI.
Hadad, M.D., W. Santoso dan Ita Rulina. (2003). Indikator kepailitan di Indonesia; an additional early warning tools pada stabilitas keuangan. Direkorat Penelitian dan Pengaturan Perbankan Bank Indonesia.

Haryadi .S (tt). Analisis Laporan Keuangan Sebagai Alat Prediksi Kemungkinan Kebangkrutan Dengan Model Diskriminan Almant Pada Sepuluh Perusahaan Properti Di Bursa Efek Indonesia. Universitas Bunda Mulia.

Hafiz dan Dicky (tt). Analisis Kebangkrutan Model Altman Z-Score Dan Springate Pada Perusahaan Industri Property

ICMD (Indonesian Capital Market Directory) Perusahaan Perbankan Periode 2002 - 2007

Luciana, S. A. (2006). Prediksi Kondisi Financial Distress Perusahaan Go Public Dengan Menggunakan Analisis Multinomial Logit. Jurnal Ekonomi dan Bisnis. Vol. XII No. 1, Maret 2006. ISSN: 0854 9087.

Luciana dan Emanuel (2003). Analisis Rasio Keuangan Untuk Memprediksi Kondisi Financial Distress Perusahaan Manufaktur Yang Terdaftar Di Bursa Efek Jakarta. Jurnal Akuntansi dan Auditing Indonesia Vol. 7 No.2.

Luciana, S. A.(2004). Analisis faktor-faktor yang mempengaruhi kondisi financial distress suatu perusahaan yang terdaftar di Bursa Efek Jakarta. Jurnal Riset Akuntansi Indonesia(JRAI), Vol 7. No.1.

Peter dan Yoseph. (2011). Analisis Kebangkrutan Dengan Metode Zscore Almant, Springate Dan 
Zmijewski Pada PT. Indofood Sukses Makmur Tbk Periode 20052009. Akurat Jurnal Ilmiah Akuntansi Nomor 04 Tahun ke-2 Januari-April 2011.

Riyanto, Bambang. (2001). Dasar-Dasar Pembelanjaan Perusahaan. Yogyakarta: BPFE.

Siamat, Dahlan (2004). Manajemen Lembaga Keuangan .Jakarta: Lembaga Penerbit Fakultas Ekonomi Universitas Indonesia

Sitompul, Zulkarnain (2007). Lembaga Penjamin Simpanan, Substansi dan Permasalahan. Bandung: Books \& Library.
Sugiyono (2008). Metode Penelitian Bisnis.Bandung: Alfabeta

Taswan (2005). Akuntansi Perbankan. Yogyakarta: UPP AMP YKPN Undang-Undang Republik Indonesia No. 10 Tahun 1998 tentang "Perbankan".

Undang-Undang Republik Indonesia No. 24 Tahun 2004 tentang "Lembaga Penjamin Simpanan".

www.lps.go.id (situs resmi Lembaga Penjamin Simpanan)

Perbandingan

Ketepatan Klasifikasi Model Prediksi Kepailitan Berbasis Akrual Dan Berbasis Aliran Kas. SNA VIII Solo. 